\title{
A Progressive Assessment of Pharmacy Undergraduates' Motivation and Satisfaction towards Pharmacy as a Professional Choice
}

\author{
Bisma Sajjad, Rabia Ishaq, Qaiser Iqbal, Fahad Saleem* \\ Faculty of Pharmacy and Health Sciences, University of Balochistan, Quetta, PAKISTAN.
}

Received: 7 Feb 2021;
Accepted: 28 Mar 2021
*Correspondence to:
Dr. Fahad Saleem,
Faculty of Pharmacy and Health Sciences,
University of Balochistan, Quetta, PAKISTAN.
Email: fahaduob@gmail.com
Copyright: C the author(s),publisher and
licensee Indian Academy of Pharmacists. This
is an open-access article distributed under the
terms of the Creative Commons Attribution
Non-Commercial License, which permits
unrestricted non-commercial use, distribution,
and reproduction in any medium, provided the
original work is properly cited.

\section{INTRODUCTION}

Nearly all students have their own, distinctly unique, motivations and expectations about their professional career. Unquestionably, such motivations and expectations are driven through different factors. Where motivation is the biological, social, and psychological state that drives a person towards specific action, ${ }^{[1]}$ expectation is a strong belief that something will happen or be the case. ${ }^{[2]}$ Inline to what is being discussed; students' satisfaction and expectation has always been a major concern for universities as it plays a vital role in determining student success and retention thus building their national economies. Therefore, higher educational institutes continuously implement quality assurance programs to evaluate their students' satisfaction and expectation claiming that it has a major impact on student performance. ${ }^{[3]}$ Many universities prefer a clear accountability process for upgrading the facilities provided to students, faculty and staff and for this purpose satisfaction and expectations remain the preceding component. ${ }^{[4]}$

Within this context, few studies have measured the inspirational drivers at different preregistration stages which affect choosing pharmacy as a profession. ${ }^{[5-7]}$ Likewise first year undergraduate students motivation was assessed by Rees in several pharmacy schools. ${ }^{[8]}$ Ferguson et al. (1986) evaluated motivation and influences of 315 first year pharmacy students in three different schools, in Australia, Canada and the United States. All these studies investigated motivational factors and recommended to investigate students' perception and knowledge of pharmacy students at the time of admission. ${ }^{\left[{ }^{[9}\right.}$ Logical and professional counseling for pre-pharmacy students concerning the pharmaceutical career and the possible employment opportunities would lead students toward determining their career of interest, as well as helping them to map their future career plan. ${ }^{[10]}$ Furthermore, Elliott and Healy concluded that satisfaction can only be attained if student's conduct and real experiences met or surpassed their expectancy. ${ }^{[1]}$ Opting pharmacy as an academic course is a difficult task due to greater educational burden. ${ }^{[12,13]}$ Therefore, students joining a pharmacy program should be clear about its prerequisites, challenges and opportunities for its successful completion.

Shifting our concerns to pharmacy education in Pakistan, a three year pharmacy degree program was offered by University of Punjab, Lahore in 1948 which was then extended to four year Bachelors of Pharmacy program (B.Pharm) in 1978-1979. In the vague to meet international standards, Higher Education Commission (HEC) of Pakistan reformed the pharmacy curriculum, established faculties and upgraded the four years B.Pharm program to five years Doctor of Pharmacy (Pharm.D). Parallel to compensate this one year gap, a condensed/crash Pharm.D course was offered to the B.Pharm graduates that awarded them with a certificate equivalent to Pharm-D. Today a 5 year Doctor of Pharmacy (Pharm.D) is offered by the pharmacy schools of the country. Pharmacy is one of the globally accepted 
reputable professions and has experienced enormous progress over the years. ${ }^{[14]}$ Due to the rising need of its graduates; it is one of the most desirable specialties in Pakistan. However, the predictors and factors that urge students to opt for pharmacy profession as a carrier in Pakistan are least discussed in literature. We have to remember that exploring student' satisfaction and motivation while considering pharmacy as a career is highly important as this lay the foundation for future success and graduation. Therefore, students' evaluations of the social and academic aspects of the institutes can provide the policymakers important insights into the students' overall experiences and expectations while electing pharmacy as a professional career. Also it is believed that understanding of the motivation and expectations of pharmacy undergraduates will provide a foundation for further research on student aspirations and perceptions while selecting pharmacy as a profession. Therefore, the current study is aimed to access the motivation, satisfaction and expectations of Pharm-D undergraduate towards pharmacy as a profession while attending a public university of Quetta city, Pakistan.

\section{METHODS}

Study design and settings: This was a questionnaire based, cross-sectional analysis. The research was carried out at Faculty of Pharmacy and Health Sciences, University of Balochistan Quetta, Pakistan. Pharmacy program was introduced in 1980 and being the pioneer institute of pharmacy in the province offers huge attraction to the promising undergraduates from all over the province.

\section{Study population, sampling, inclusion and exclusion criteria}

By employing an availability sampling approach, all students registered in Pharm.D program (other than first professional year) at Faculty of Pharmacy and Health Sciences were approached for data collection. Students registered in other study disciplines and those not willing to participate were excluded from the study.

\section{Study tool (development, reliability and validity)}

The research tool was constructed by the research team through extensive literature review. For this purpose, part of the statements of the tool was developed by the study frame work of King (2013) and Wison et al. 2006. ${ }^{[15,16]}$ The tool was validated for face and content validity by experts at Faculty of Pharmacy and Health Sciences, University of Balochistan, Quetta. Later, the tool was subjected to pilot study with ten (10) undergraduates and little modification was needed. The tool was rated as reliable with an alpha value of $0.78 \cdot{ }^{[17]}$ Data from the pilot study was not included in the main study.

\section{Data collection and ethical considerations}

The first author was involved in data collection. The study' purpose as well as addressing confidentiality matters, where no disclosure of personal data was assured to the respondents. Institutional Ethical Committee of Faculty of Pharmacy and Health Sciences, University of Balochistan approved the study protocol. Written consent was also taken from the respondent.

\section{Data coding and statistical analysis}

The data was coded and transferred to Statistical Package for Social Science v 21.0. Based on the objectives of the study, descriptive analysis was performed to present the frequency and percentage demographic characteristics and other study variables.

\section{RESULTS}

Demographic characteristics of the study respondents

The demographics are illustrated in Table 1. Out of 620 enrolled students, 475 respondents were involved in the survey with a response rate of $76.6 \%$. Majority $(337,70.9 \%)$ were in the age range of $21-23$ year. Males dominated the cohort $(330,69.4 \%)$ and the distribution of students in third and fourth professional year was almost equal $(\leq 27 \%)$. Three hundred and eighteen $(66.9 \%)$ had urban residencies and only $42.3 \%$ opted the profession of Pharmacy as their first choice.

\section{Description of educational influencers while opting pharmacy as a career}

The educational influencers that effected on the selection of pharmacy as a career are presented in Table 2 . Almost $60 \%$ of the respondents reported that they chose pharmacy as a career based on the information available from the university prospectus. Followed by the prospectus, visit to a conference / career fair was the other influencer whereby almost 45\% either strongly agreed or agreed to the statement.

\section{Description of social influencers while opting pharmacy} as a career

Social influencers for selecting pharmacy as a career are presented in Table 3. Fifty-eight percent of the pharmacy undergraduates chose pharmacy as a career based upon the recommendations of their parents followed by the suggestions of their family members $(50.0 \%)$.

\section{Table 1: Demographic characteristics of the study} respondents.

\begin{tabular}{|c|c|c|}
\hline Characteristics & Frequency & Percentage \\
\hline $\begin{array}{l}\text { Age }(21.97 \pm 1.53) \\
18-20 \\
21-23 \\
24-26\end{array}$ & $\begin{array}{l}74 \\
337 \\
64\end{array}$ & $\begin{array}{l}15.5 \\
70.9 \\
13.4\end{array}$ \\
\hline $\begin{array}{l}\text { Gender } \\
\text { Male } \\
\text { Female }\end{array}$ & $\begin{array}{l}330 \\
145\end{array}$ & $\begin{array}{l}69.4 \\
30.5\end{array}$ \\
\hline $\begin{array}{l}\text { Marital status } \\
\text { Unmarried } \\
\text { Married }\end{array}$ & $\begin{array}{l}460 \\
15\end{array}$ & $\begin{array}{l}96.8 \\
3.2\end{array}$ \\
\hline $\begin{array}{l}\text { Ethnic group } \\
\text { Pathan } \\
\text { Baloch } \\
\text { Punjabi } \\
\text { Sindhi } \\
\text { Other }\end{array}$ & $\begin{array}{l}150 \\
212 \\
69 \\
10 \\
34\end{array}$ & $\begin{array}{l}31.5 \\
44.6 \\
14.5 \\
2.10 \\
7.15\end{array}$ \\
\hline $\begin{array}{l}\text { Year of study } \\
\text { 2nd year } \\
\text { 3rd year } \\
\text { 4th year } \\
\text { 5th year }\end{array}$ & $\begin{array}{l}112 \\
126 \\
127 \\
110\end{array}$ & $\begin{array}{l}23.5 \\
26.5 \\
26.7 \\
23.1\end{array}$ \\
\hline $\begin{array}{l}\text { Locality } \\
\text { Rural } \\
\text { Urban }\end{array}$ & $\begin{array}{l}157 \\
318\end{array}$ & $\begin{array}{l}33.1 \\
66.9\end{array}$ \\
\hline $\begin{array}{l}\text { Academic session } \\
\text { Morning } \\
\text { Evening }\end{array}$ & $\begin{array}{l}262 \\
213\end{array}$ & $\begin{array}{l}55.1 \\
44.8\end{array}$ \\
\hline $\begin{array}{l}\text { Pharmacy as a first-choice carrier } \\
\text { Yes } \\
\text { No }\end{array}$ & $\begin{array}{l}201 \\
274\end{array}$ & $\begin{array}{l}42.3 \\
57.6\end{array}$ \\
\hline
\end{tabular}


Description of personal influencers while opting pharmacy as a career

Working with patients and in the medical field was the biggest influencers for the pharmacy undergraduates as $\leq 90 \%$ of the students agreed to this statement. Additionally, job with a good career opportunity was also ranked as a influencer by the respondents (85\%). Almost $80 \%$ of the pharmacy undergraduates reported their interest in science and science-based subjects as a major influence of selecting pharmacy as a career. The other influencers for choosing pharmacy as a carrier as presented in Table 4.

\section{Satisfaction towards pharmacy as a career}

The satisfaction towards pharmacy is presented in Table 5. Majority of the students $(\leq 80 \%)$ were committed to the profession' ideology and were content studying pharmacy. Sixty percent disagreed that they will change their profession if a chance is provided and $81 \%$ stated to continue their career as a pharmacist. Pharmacy was seen as an ideal profession by $65 \%$ of the respondents $45 \%$ had no regrets in selecting pharmacy as a carrier while $24 \%$ remained neutral to this statement.

\section{DISCUSSION}

Student motivation has been given low consideration in pharmaceutical education and curricular reforms are not geared towards enhancing student

Table 2: Description of educational influencers when opting pharmacy as a carrier.

\begin{tabular}{|l|c|l|l|l|l|}
\hline Influencers & $\begin{array}{l}\text { SA } \\
\text { N (\%) }\end{array}$ & $\begin{array}{l}\text { A } \\
\mathbf{N}(\%)\end{array}$ & $\begin{array}{l}\mathbf{N} \\
\mathbf{N}(\%)\end{array}$ & $\begin{array}{l}\text { DA } \\
\mathbf{N} \\
(\%)\end{array}$ & $\begin{array}{l}\text { SDA } \\
\mathbf{N} \\
(\%)\end{array}$ \\
\hline $\begin{array}{l}\text { A subject teacher at } \\
\text { school or college }\end{array}$ & $40(8.4)$ & $\begin{array}{l}123 \\
(25.9)\end{array}$ & $110(23.2)$ & $\begin{array}{l}167 \\
(35.2)\end{array}$ & $\begin{array}{l}35 \\
(7.4)\end{array}$ \\
\hline $\begin{array}{l}\text { A career's teacher at } \\
\text { school }\end{array}$ & $46(9.7)$ & $\begin{array}{l}156 \\
(32.8)\end{array}$ & $99(20.8)$ & $\begin{array}{l}141 \\
(29.7)\end{array}$ & $\begin{array}{l}33 \\
(6.9)\end{array}$ \\
\hline $\begin{array}{l}\text { A visit to a career's } \\
\text { fair/ conference }\end{array}$ & $55(11.6)$ & $\begin{array}{l}158 \\
(33.3)\end{array}$ & $119(25.1)$ & $\begin{array}{l}126 \\
(26.5)\end{array}$ & $\begin{array}{l}17 \\
(3.6)\end{array}$ \\
\hline $\begin{array}{l}\text { A university } \\
\text { prospectus }\end{array}$ & $74(15.6)$ & $\begin{array}{l}220 \\
(46.3)\end{array}$ & $90(18.9)$ & $\begin{array}{l}61 \\
(12.58)\end{array}$ & $\begin{array}{l}30 \\
(6.3)\end{array}$ \\
\hline $\begin{array}{l}\text { Mass and social } \\
\text { media }\end{array}$ & $26(5.5)$ & $\begin{array}{l}92 \\
(19.4)\end{array}$ & $112(23.6)$ & $\begin{array}{l}165 \\
(34.7)\end{array}$ & $\begin{array}{l}80 \\
(16.8)\end{array}$ \\
\hline
\end{tabular}

Table 3: Description of social influencers when opting pharmacy as a carrier.

\begin{tabular}{|c|c|c|c|c|c|}
\hline Influencers & $\begin{array}{l}\text { SA } \\
\text { N (\%) }\end{array}$ & $\begin{array}{l}\text { A } \\
\mathbf{N}(\%)\end{array}$ & $\begin{array}{l}\mathbf{N} \\
\mathbf{N}(\%)\end{array}$ & $\begin{array}{l}\text { DA } \\
\text { N } \\
(\%)\end{array}$ & $\begin{array}{l}\text { SDA } \\
\text { N (\%) }\end{array}$ \\
\hline $\begin{array}{l}\text { My parents } \\
\text { encouraged me to } \\
\text { choose pharmacy }\end{array}$ & $\begin{array}{l}125 \\
(26.3)\end{array}$ & $\begin{array}{l}151 \\
(31.8)\end{array}$ & $54(11.4)$ & $\begin{array}{l}110 \\
(23.2)\end{array}$ & $35(7.4)$ \\
\hline $\begin{array}{l}\text { My family encouraged } \\
\text { me to choose } \\
\text { pharmacy }\end{array}$ & $85(17.9)$ & $\begin{array}{l}153 \\
(32.2)\end{array}$ & $64(13.5)$ & $\begin{array}{l}125 \\
(26.3)\end{array}$ & $\begin{array}{l}48 \\
(10.01)\end{array}$ \\
\hline $\begin{array}{l}\text { Someone in my } \\
\text { family who owns a } \\
\text { pharmacy influenced } \\
\text { me }\end{array}$ & $75(15.8)$ & $\begin{array}{l}115 \\
(24.2)\end{array}$ & $44(9.3)$ & $\begin{array}{l}175 \\
(36.8)\end{array}$ & $\begin{array}{l}66 \\
(13.9)\end{array}$ \\
\hline $\begin{array}{l}\text { My friends/social } \\
\text { circle influenced me }\end{array}$ & $76(16.0)$ & $\begin{array}{l}115 \\
(24.2)\end{array}$ & 63 (13.3) & $\begin{array}{l}163 \\
(34.3)\end{array}$ & $\begin{array}{l}58 \\
(12.2)\end{array}$ \\
\hline
\end{tabular}

motivation. Studying motivation through an approach giving importance to both the quality and quantity of motivation is recommended. Intrinsic motivation (learning for the sake of learning) leads to better learning and performance as compared with extrinsic motivation (learning for reward), and can be enhanced by providing students with autonomy in learning, feedback on their performance, and emotional support. ${ }^{[18]}$ Therefore, the current study was aimed to access the motivation and satisfaction levels of undergraduate Pharm.D students towards pharmacy as a profession visiting a public university of Quetta city, Pakistan.

More than half of the respondents reported that pharmacy was not their first choice. It is obvious that students do prefer opting for medical sciences and always place pharmaceutical sciences as an alternative. Our findings are supported when compared with studies of the same nature. ${ }^{[19-21]} \mathrm{A}$ possible reason is the poor awareness and acceptability of the pharmacy profession in the societies. ${ }^{[16,22]}$ Although the profession of pharmacy have come a long way, there is substantial distance to cover before the profession is accepted by the societies when compared to medical sciences.

While discussing satisfaction, majority of the students $(\leq 80 \%)$ were satisfied while studying pharmacy. Sixty percent disagreed that they will change their profession if a chance is provided and $81 \%$ stated to continue their career as a pharmacist. Within this context, Shen and colleagues have described complex factors that shape students' satisfaction and perception of career. ${ }^{[23]}$ This is also relatable to the current scenario as pharmacy profession had reshaped in the last 10 years in Balochistan. There are opportunities in the community pharmacy sector, the acceptability of the pharmacist at the practicing sites is increasing and added understanding of the pharmaceutical industry. Furthermore, with the development of the service structure, the future of pharmacy profession is well established and that is related to the satisfaction of the students. Nevertheless, this is based on our personal experience and

\section{Table 4: Description of personal influencers when opting} pharmacy as a carrier.

\begin{tabular}{|c|c|c|c|c|c|}
\hline Influencers & $\begin{array}{l}\text { SA } \\
\mathbf{N}(\%)\end{array}$ & $\begin{array}{l}\text { A } \\
\mathbf{N}(\%)\end{array}$ & $\begin{array}{l}\mathbf{N} \\
\mathbf{N}(\%)\end{array}$ & $\begin{array}{l}\text { DA } \\
\text { N (\%) }\end{array}$ & $\begin{array}{l}\text { SDA } \\
\text { N }(\%)\end{array}$ \\
\hline $\begin{array}{l}\text { I liked science/was } \\
\text { good at science at } \\
\text { school }\end{array}$ & $\begin{array}{l}206 \\
(43.4)\end{array}$ & $\begin{array}{l}236 \\
(49.7)\end{array}$ & $16(3.4)$ & $13(2.7)$ & $4(0.8)$ \\
\hline $\begin{array}{l}\text { I liked science-based } \\
\text { course }\end{array}$ & $\begin{array}{l}222 \\
(46.7)\end{array}$ & $\begin{array}{l}195 \\
(41.1)\end{array}$ & $30(6.3)$ & $18(3.8)$ & $10(2.1)$ \\
\hline $\begin{array}{l}\text { I wanted to take a } \\
\text { science-based course } \\
\text { as a career }\end{array}$ & $\begin{array}{l}290 \\
(61.1)\end{array}$ & $\begin{array}{l}150 \\
(31.6)\end{array}$ & $15(3.2)$ & $12(2.5)$ & $8(1.7)$ \\
\hline $\begin{array}{l}\text { I wanted a job } \\
\text { with good career } \\
\text { opportunities }\end{array}$ & $\begin{array}{l}282 \\
(59.4)\end{array}$ & $\begin{array}{l}469 \\
(35.6)\end{array}$ & $10(2.1)$ & $6(1.3)$ & $8(1.7)$ \\
\hline $\begin{array}{l}\text { I wanted to work with } \\
\text { patients }\end{array}$ & $\begin{array}{l}217 \\
(45.7)\end{array}$ & $\begin{array}{l}162 \\
(34.1)\end{array}$ & $66(13.9)$ & $23(4.8)$ & $7(1.5)$ \\
\hline $\begin{array}{l}\text { I wanted to own my } \\
\text { personal business }\end{array}$ & $\begin{array}{l}157 \\
(33.1)\end{array}$ & $\begin{array}{l}126 \\
(26.5)\end{array}$ & $95(20.0)$ & $\begin{array}{l}78 \\
(16.4)\end{array}$ & $19(4.0)$ \\
\hline $\begin{array}{l}\text { I was attracted by the } \\
\text { financial rewards }\end{array}$ & $\begin{array}{l}99 \\
(20.8)\end{array}$ & $\begin{array}{l}127 \\
(26.7)\end{array}$ & $\begin{array}{l}129 \\
(27.2)\end{array}$ & $\begin{array}{l}92 \\
(19.4)\end{array}$ & $28(5.9)$ \\
\hline $\begin{array}{l}\text { I wanted flexible } \\
\text { working hours }\end{array}$ & $\begin{array}{l}133 \\
(28.0)\end{array}$ & $\begin{array}{l}181 \\
(38.1)\end{array}$ & $92(19.4)$ & $\begin{array}{l}56 \\
(11.8)\end{array}$ & $13(2.7)$ \\
\hline $\begin{array}{l}\text { I wanted to work with } \\
\text { medicine/in the medical } \\
\text { profession }\end{array}$ & $\begin{array}{l}289 \\
(60.8)\end{array}$ & $\begin{array}{l}139 \\
(29.3)\end{array}$ & $20(4.2)$ & $19(4.0)$ & $8(1.7)$ \\
\hline $\begin{array}{l}\text { I wanted to study } \\
\text { medicine/dentistry } \\
\text { or another medically } \\
\text { related subject }\end{array}$ & $\begin{array}{l}250 \\
(52.6)\end{array}$ & $\begin{array}{l}161 \\
(33.9)\end{array}$ & $32(6.7)$ & $20(4.2)$ & $12(2.5)$ \\
\hline
\end{tabular}


Sajjad, et al.: Pharmacy Undergraduates' Motivation and Satisfaction towards Pharmacy

\begin{tabular}{|c|c|c|c|c|c|}
\hline Influencers & $\begin{array}{l}\text { SA } \\
\text { N (\%) }\end{array}$ & $\begin{array}{l}\text { A } \\
\text { N (\%) }\end{array}$ & $\begin{array}{l}N \\
N \\
(\%)\end{array}$ & $\begin{array}{l}\text { DA } \\
N \\
(\%)\end{array}$ & $\begin{array}{l}\text { SDA } \\
\text { N } \\
(\%)\end{array}$ \\
\hline $\begin{array}{l}\text { I am proud to tell others } \\
\text { that I am studying } \\
\text { pharmacy }\end{array}$ & $\begin{array}{l}250 \\
(52.6)\end{array}$ & $\begin{array}{l}151 \\
(31.8)\end{array}$ & $41(8.6)$ & $11(2.3)$ & $\begin{array}{l}22 \\
(4.6)\end{array}$ \\
\hline $\begin{array}{l}\text { I am strongly committed } \\
\text { to the values and } \\
\text { ideals of the pharmacy } \\
\text { profession }\end{array}$ & $\begin{array}{l}209 \\
(44.0)\end{array}$ & $\begin{array}{l}184 \\
(38.7)\end{array}$ & $47(9.9)$ & $22(4.6)$ & $\begin{array}{l}13 \\
(2.7)\end{array}$ \\
\hline $\begin{array}{l}\text { Being a pharmacist is an } \\
\text { important part of who I } \\
\text { want to be }\end{array}$ & $\begin{array}{l}218 \\
(45.9)\end{array}$ & $\begin{array}{l}165 \\
(34.7)\end{array}$ & $\begin{array}{l}56 \\
(11.8)\end{array}$ & $24(5.1)$ & $\begin{array}{l}12 \\
(2.5)\end{array}$ \\
\hline $\begin{array}{l}\text { If I could pick a different } \\
\text { occupation which paid } \\
\text { the same amount, I } \\
\text { would probably change } \\
\text { degree }\end{array}$ & $\begin{array}{l}57 \\
(12.0)\end{array}$ & $\begin{array}{l}61 \\
(12.8)\end{array}$ & $\begin{array}{l}74 \\
(15.6)\end{array}$ & $\begin{array}{l}216 \\
(45.5)\end{array}$ & $\begin{array}{l}67 \\
(14.1)\end{array}$ \\
\hline $\begin{array}{l}\text { I want a career in } \\
\text { pharmacy }\end{array}$ & $\begin{array}{l}251 \\
(52.8)\end{array}$ & $\begin{array}{l}150 \\
(31.6)\end{array}$ & $\begin{array}{l}55 \\
(11.6)\end{array}$ & $6(1.3)$ & $\begin{array}{l}13 \\
(2.7)\end{array}$ \\
\hline $\begin{array}{l}\text { If I could do it all over } \\
\text { again, I would choose } \\
\text { to study for the same } \\
\text { profession }\end{array}$ & $\begin{array}{l}118 \\
(24.8)\end{array}$ & $\begin{array}{l}134 \\
(28.2)\end{array}$ & $\begin{array}{l}94 \\
(19.8)\end{array}$ & $\begin{array}{l}84 \\
(17.7)\end{array}$ & $\begin{array}{l}45 \\
(9.5)\end{array}$ \\
\hline $\begin{array}{l}\text { Pharmacy is the ideal } \\
\text { profession for a career } \\
\text { for life }\end{array}$ & $\begin{array}{l}166 \\
(34.9)\end{array}$ & $\begin{array}{l}150 \\
(31.6)\end{array}$ & $\begin{array}{l}96 \\
(20.2)\end{array}$ & $44(9.3)$ & $\begin{array}{l}19 \\
(4.0)\end{array}$ \\
\hline $\begin{array}{l}\text { I regret that I entered } \\
\text { pharmacy school }\end{array}$ & $\begin{array}{l}67 \\
(14.1)\end{array}$ & $\begin{array}{l}92 \\
(19.4)\end{array}$ & $\begin{array}{l}114 \\
(24.0)\end{array}$ & $\begin{array}{l}143 \\
(30.1)\end{array}$ & $\begin{array}{l}59 \\
(12.4)\end{array}$ \\
\hline $\begin{array}{l}\text { I intend to take a second } \\
\text { degree after completing } \\
\text { pharmacy }\end{array}$ & $\begin{array}{l}115 \\
(24.2)\end{array}$ & $\begin{array}{l}142 \\
(29.9)\end{array}$ & $\begin{array}{l}89 \\
(18.7)\end{array}$ & $\begin{array}{l}84 \\
(17.7)\end{array}$ & $\begin{array}{l}45 \\
(9.5)\end{array}$ \\
\hline
\end{tabular}

we do agree that a thorough investigation is needed to highlight the factors that lead to the satisfaction of the pharmacy undergraduates.

As a student, apprentices are often faced with decision making issues especially when it comes to career selection. Choosing a career is influenced by many factors and the most important is the influence of teachers on students when choosing as a career. ${ }^{[24,25]}$ On the other hand, the data at EAFP Conference in Estonia revealed that approximately 12\% of first year pharmacy students found no importance of teachers' influence. However, this finding is of no value for the current study because first year students were not included in the current study and hence the comparison is unjustified.

In Fiji, Japan, students of different ethnicity also received career advices from their teachers. Male and female ethnic-Fijian students with respective percentages of $49 \%$ and $50.6 \%$ had a higher percentage of influence by teachers compared to male and female Indo-Fijian students with respective percentages of $32.1 \%$ and $42.8 \%{ }^{[26]}$ This may be due to the lack of educational opportunities and crucial poverty happening among some of the Indo-Fijian community. ${ }^{[27]}$ Hence, leading to less Indo-Fijian students able to attend school and affecting the percentage of students influenced by teachers. The data in our research is opposite to what was conducted in Fiji as ethnic group had no association as a social influencer while selecting pharmacy. Despite having a steady divergence among the two studies, data, reasons and evidences of this difference is not reported in literature and can be attributed to students' perception and attitudes. Other possible reasons could be the teachers' passion, commitment and perhaps management or vice versa.

Unexpected growth in medication use has escalated demand for pharmacists that has outpaced supply. ${ }^{[28]}$ As we all already aware of, pharmacy is a demanding profession where the graduates can always get a job. According to our findings, majority of the respondents answer that the job availability factor is a very important factor in choosing pharmacy as their lifelong career. Our findings are supported and similar to a research done by Hassell. ${ }^{[2]}$ Youth of the age range 18-22 normally starts to plan for their future and instinctively they will sure consider profession where they can always get a job after they graduated to ensure a comfortable life.

Also, majority of our respondents wanted to work in a well-respected profession. Both male and female students classified to work in a wellrespected profession of their importance. ${ }^{[30]}$ In today's' world, everyone wants to work in respected profession regardless of gender, ethnicity and age group. However, based on the findings of the research, there are females applying for pharmacy compared to males because woman has limited options for a professional career unlike men who also have many opportunities in specializing (like engineering) which skews towards man. These findings are consistent to a study conducted by the Aston University which states that there were more female applicants to pharmacy compared to men according to the data shown from 1998 to $2002 \cdot{ }^{[30]}$ This is because females opt for a job which is socially useful and has a flexible schedule. In another study conducted by the School of Pharmacy of Samford University, more female students (mean response $=4.54$ ) compared to male students (mean response $=4.12$ ) said that a flexible work schedule is important. ${ }^{[31]} \mathrm{A}$ flexible schedule is possibly one of the reasons why pharmacy is more preferred by woman as an ideal profession for a career in life. It may be because female students need to think of their future when they have families. Having a flexible schedule helps them in fulfilling their role as caretakers for their family. Not only that, Savage et al. also had findings which stated that benefit packages may be a valid reason to why more female students compared to male students agreed that pharmacy is an ideal profession for a career in life. It is possibly because of the difference in future aspirations and different levels of maturity among the students.

In our study, most of the students chose pharmacy as their career because they thought that being a pharmacist is an important part of who they want to be. They were generally positive about pharmacy as a future career and satisfied with their decision to choose it as a subject to study and as a career. ${ }^{[32]}$ This might due to the professional advancement opportunities in pharmacy, ability to shape the profession's future and its academic environment. ${ }^{[33]}$ Other reasons might because of the benefits provided in this field such as vacation time, health insurance policies, bonus packages and its flexible working schedule. Certainly, many pharmacy careers offer more flexible scheduling than it is found in other health care fields. ${ }^{[31]}$ Besides that, pharmacist was seen as an important part because they desired for a satisfying and self-fulfilling position, job security, sense of accomplishment, opportunity to use one's ability and education to serve the community. ${ }^{[34]}$

\section{CONCLUSION}

Despite some of the limitations faced, the results do have important implications. Impact of family and friends, looking for an in-demand job with good career opportunities, and the desire to work in a health-related field were the main influencing factors in pharmacy students' decision to study pharmacy. It is obvious from the findings that there is a need to guide high school students regarding their choice of undergraduate programs, and for these students to be made aware of the challenges and opportunities of studying pharmacy.

\section{ACKNOWLEDGEMENT}

The authors acknowledge the students for their participation in the study. 


\section{Limitations}

A major limitation was the response rate and that may be a reason why problems were faced during data tabulation. Also, being a single centered study, comparison and contrast with a huge data set was not possible. Perhaps a generalized research involving more pharmacy schools can give a better picture. Involving other universities and institutions will also increase the sample size which allows a more accurate result to be produced as a larger sample size reduces sampling errors.

\section{CONFLICT OF INTEREST}

The authors have no conflict of interest to disclose.

\section{REFERENCES}

1. Study and exam. Motivation. 2018. [cited 25 December, 2020]. Available from: https://www.studyandexam.com/motivation-meaning-types.html.

2. Merriam-Webster. Expectation. 2021. [cited 10 January 2021]. Available from: https://www.merriam-webster.com/dictionary/expectation.

3. Bryant J, Bodfish S. The Relationship of Student Satisfaction to Key Indicators for Colleges and Universities. 2014 National Research Report. Noel-Levitz, Inc; 2014.

4. Browne BA, Kaldenberg DO, Browne WG, Brown DJ. Student as customer: Factors affecting satisfaction and assessments of institutional quality. J Mark High Educ.1998;8(3):1-14.

5. Booth T, Harkiss K, Linley P. Factors in the choice of pharmacy as a career. Pharm J. 1984;233(6298):420.

6. Mostafavi S, Ramezanloo P, Asgari N. Pharmacy students'reasons for choosing pharmacy as a career and changes in their motivation during the course. J Med Educ Dev. 2013;5(9):33-42.

7. Sharif SI, Sharif RS. Choosing pharmacy as a major: Motivations and influences. Pharm Educ. 2014;14(1):116-20.

8. Rees J. Why male and female students choose to study pharmacy. Brit J Gen Pract. 1984;7:90-6.

9. Jesson JK, Langley C, Wilson K. Factors influencing students in choosing to study pharmacy in Great Britain. Pharm J. 2009;282(7557):750-3.

10. Alhaddad MS. Undergraduate pharmacy students' motivations, satisfaction levels, and future career plans. J Taibah Univ Medical Sci. 2018;13(3):247-53.

11. Elliott KM, Healy MA. Key factors influencing student satisfaction related to recruitment and retention. J Mark High Educ. 2001;10(4):1-11.

12. Ford K, Olotu B, Thach A, Roberts R, Davis P. Factors contributing to perceived stress among doctor of pharmacy (PHARMD) students. Coll Stud J. 2014;48(2):189-98.

13. Canales-Gonzales PL, Kranz PL. Perceived stress by students in a pharmacy curriculum. Education. 2008;129(1):139-47.

14. Pearson GJ. Evolution in the practice of pharmacy—not a revolution!. Can Med Assoc J. 2007;176(9):1295-6.

15. King MD. Motivation and education: Performance, commitment, and satisfaction among pharmacy students. Montana, USA: The University of Montana; 2013.

16. Wilson K, Jesson J, Langley C, Hatfield K, Clarke L. Pharmacy undergraduate students: career choices and expectations across a four-year degree programme. London: Royal Pharmaceutical Society of Great Britain. 2006;74-93.
17. Wikman A. Reliability, validity and true values in surveys. Soc Indic Res. 2006;78(1):85.

18. Kusurkar R. Motivation in medical students: $A$ PhD thesis report. Springer; 2012.

19. James PB, Batema MNP, Bah AJ, Brewah TS, Kella AT, Lahai M, et al. Was Pharmacy their preferred choice? Assessing pharmacy students' motivation to study pharmacy, attitudes and future career intentions in Sierra Leone. Health Prof Educ. 2018;4(2):139-48.

20. Beedemariam G, Ebro M, Ageze H, Weldegerima B, Legesse B, Tilahun G. Pharmacy students' attitude and future career choices: A survey of four public schools of pharmacy in Ethiopia. Ethiopian Pharm J. 2014;30(1):57-63.

21. Modipa SI, Dambisya YM. Profile and career preferences of pharmacy students at the University of Limpopo, Turfloop Campus, South Africa. Educ Health. 2008;21(3):164

22. JrAnderson DC, Sheffield MC, Hill AM, Cobb HH. Influences on pharmacy students' decision to pursue a doctor of pharmacy degree. Am J Pharm Educ. 2008;72(2):22.

23. Shen G, Fois R, Nissen L, Saini B. Course experiences, satisfaction and career intent of final year pre-registration Australian pharmacy students. Pharm Prac. 2014;12(2):392.

24. Quinter M, Edwards K. Factors influencing students career choices among secondary school students in Kisumu municipality, Kenya. Journal of Emerging Trends in Educational Research and Policy Studies. 2011;2(2):81-7.

25. Briley DA, Morris MW, Simonson I. Reasons as carriers of culture: Dynamic versus dispositional models of cultural influence on decision making. $J$ Consum Res. 2000;27(2):157-78.

26. Rennie LJ, Dunne M. Gender, Ethnicity, and Students' Perceptions about Science and Science-Related Careers in Fiji. Science Education. 1994;78(3):296.

27. Kumar S, Prasad B. Politics of race and poverty in Fiji. Int J Soc Econ. 2004;31(5/6):469-86.

28. Cooksey JA, Knapp KK, Walton SM, Cultice JM. Challenges to the pharmacist profession from escalating pharmaceutical demand. Health Aff. 2002;21(5):182-8.

29. Hassell $K$. White and ethnic minority pharmacists' professional practice patterns and reasons for choosing pharmacy. Int J Pharm Prac. 1996;4(1):43-51.

30. Wilson K, Jesson J, Hatfield K, Langley C. A Career in Pharmacy: A New Approach to Measuring the Motivations of Pharmacy Students. EAFP Conference, Estonia; 2006.

31. Savage LM, Beall JW, Woolley TW. Factors That Influence the Career Goals of Pharmacy Students. Am J Pharm Educ. 2009;73(2):1-5.

32. Wilson K, Jesson J, Langley C, Hatfield K, Clarke L. Pharmacy undergraduate students: Career choices and expectations across a four-year degree programme. London: Royal Pharmaceutical Society of Great Britain. 2006;74-93.

33. Sheaffer EA, Brown BK, Byrd DC, Gupchup GV, Mark SM, Smith MAM, et al. Variables impacting an academic pharmacy career choice. Am J Pharm Educ. 2008;72(3).

34. Rahman AFA, Ibrahim MIM, Yusoff ZM, Bahari MB, Ismail R. Career Choice of Malaysian Pharmacy: A Preliminary Analysis. Malaysian Pharmaceutical Society. 2013. [cited 15 January 2021] Avaiable from: https://www.mps.org.my/ publications/Journal_of_Pharmacy/career_choice.htm

Cite this article as: Sajjad B, Ishaq R, Iqbal Q, Saleem F. A Progressive Assessment of Pharmacy Undergraduates' Motivation and Satisfaction towards Pharmacy as a Professional Choice. J Pharm Pract Community Med. 2021;7(1):14-18. 